\title{
Predominant factors contributing to low reading abilities of pupils at Elsie Lund Basic School in the Tamale Metropolis, Ghana
}

\section{Mohammed ${ }^{\star}$ and Ofori Amponsah}

University for Development Studies, Ghana.

Accepted 24 October, 2018

\begin{abstract}
The purpose of this study was to investigate the predominant factors contributing to low reading abilities of pupils at Elsie Lund Basic School in the Tamale Metropolis, Ghana. Purposive sampling technique was used to select twelve (12) classroom teachers of the Elsie Lund Basic School. The instrument used to collect data was one-to-one in-depth individual interview. The gathered data were analysed thematically. The analysis of the data showed the following to be the factors contributing to the low reading abilities of the pupils: their lack of confidence to practice how to read in class, poor motivation from teachers and parents to help develop the interest of the pupils in reading, lack of pre-reader books in school and at home, lack of library, teachers inadequate knowledge on phonemic awareness strategy of teaching reading, lack of reading clubs and lack of reading competition among the pupils in the school. Some recommendations were made to ensure an improvement in the reading abilities of the pupils, including: teachers building the confidence level of the pupils in reading through making them read cooperatively, the school authority supplying adequate pre-reader books to facilitate the teaching and learning of reading in the school, parents ensuring adequate supply of pre-reader books at home, parents rewarding and complementing their children for improved reading abilities, the school organising reading competitions among pupils and the school management partnering with the Ghana Education Service to organize inservice training for all language teachers on phonemic awareness strategy in teaching reading skills.
\end{abstract}

Keywords: Reading, ability, phonemic, reading skills, teaching reading.

*Corresponding author. E-mail: ssh.mohammed@yahoo.com. Tel: +233555002049 or +233542417991.

\section{INTRODUCTION}

Reading is crucial to the academic success of pupils and to the growth of a nation (Oberholzer, 2005; Oyetunji, 2011). Successful pupils in school are those who develop interest in reading because many of the subjects taught and class assignment given require reading comprehension (Darrel, 2005; Grams, 2003). Darrel (2005) and Oberholzer (2005) highlight that reading is a basic life skill and a cornerstone for success at school and throughout life; therefore, pupils who can read well can function more effectively in everyday school activities (Darrel, 2005; Oberholzer, 2005).

It is believed that reading as well as language competency are both the means and the end to educational achievement (Jordaan, 2011); as such,
Botha et al. (2008) state that pupils' language competence affect their performance in all subjects. If pupils' reading competencies are poor, then their writing competencies and their comprehension levels would also be poor (Botha et al., 2008).

While it is true that language competency is both the means and the end to educational achievement, the acquisition of its proficiency requires fluent reading nevertheless, fluency in reading is always met with a complex interaction of factors resulting to pupils' poor reading, learning and achievement (Jordaan, 2011). According to Botha et al. (2008) one of the complex factors resulting in pupils' poor reading, learning and achievement are the teachers because most of them are 
not trained to teach basic reading. They continued to state that the employment of unqualified language teachers has had a negative impact on the quality of teaching and learning of reading subjects in schools (Botha et al., 2008). In addition to the reasons for pupils' poor reading abilities in schools, Moats and Tolman (2011) assert that the majority of pupils who are poor readers and poor spellers have weak phonological processing skills (Moats and Tolman, 2011).

A number of studies on the causes of pupils' poor reading abilities have been carried out in Africa, United States of America and Asia (Njie, 2013; Rany, 2013; the National Reading Panel, 2000). The countries covered by these studies include Gambia, California and Malaysia. Some of the key contributing factors to pupils' poor reading abilities include: poor attention given to phonics instruction in class, pupils' laziness, lack of motivation to learn to read and the shifts away from phonics instruction to reading comprehension at the third grade.

Other related studies on pupils reading abilities have been conducted in countries such as South Africa (Lindner, 2008; Klapwijk and Van de Walt, 2011), United Kingdom (Cain and Oakhill, 2011) and Kenya (Lucas, 2011). According to Cain and Oakhill (2011), reading influences vocabulary development; however, when pupils do not read fluently or regularly, their vocabulary skills are impacted. Additionally, Caccamise and Snyder (2005) reported that vocabulary knowledge positively affects reading comprehension and academic performance. During reading, pupils continually process words to create meaning, and without a strong vocabulary base, students will struggle to understand what they have read (Caccamise and Snyder, 2005).

According to Lindner (2008), most pupils have low reading abilities as a result of: primary school teachers' difficulties in moving beginning readers toward immediate reading skills, pupils' lack of exposure to reading strategies and the prevailing attitude among teachers towards reading strategies. Klapwijk and Van de Walt (2011) confirmed this by stating that some primary school teachers continue to struggle with reading instruction and remain resistant to its implementation in class. Botha et al. (2008) claim many teachers have under developed understanding of teaching literacy, reading and writing. As a result, they do not know how to teach reading to pupils and they do not know how to stimulate pupils' reading both inside and outside the classroom. The question that needed to be answered in this study was: what are the predominant factors contributing to the low reading abilities of pupils at Elsie Lund Basic School in the Tamale Metropolis?

This paper examines the predominant factors contributing to pupils low reading abilities at Elsie Lund Basic School in the Tamale Metropolis. Despite the significance of reading as a cornerstone for success at school and throughout life, pupils at Elsie Lund Basic school through informal interactions with the language teachers and through informal classroom observations, it was revealed that pupils in the school have difficulties in reading basic literacy, they lack the ability to read and to understand meanings of texts, they have relative difficulty with phoneme awareness and other phonological skills employed in reading. These teachers believed that the problem of the pupils' poor reading is prevalent in many other subject areas.

\section{School and teacher factors contributing to pupils' low reading abilities}

Adebayo (2008), Botha et al. (2008) and Lindner (2008) point out that many teachers have under-developed understanding of teaching literacy and also have negative attitude towards teaching pupils reading strategies. Botha et al. (2008) claim the employment of unqualified language teachers has had a negative impact on the quality of teaching and learning of how to read. Njie (2013), Lucas (2011) and Harrington (2001) also lament that most pupils have poor literacy skills as a result of teachers incompetency and the poor teaching methodology they use to teach reading in class. It has also been highlighted by Harrington (2001) that the most significant factor in student's learning is the quality of the teacher.

Suggestions to help remedy the low reading abilities of pupils have been made by some researchers; for example, Cekiso (2012) suggests that English language teachers should provide pupils with reading strategy instruction that helps them become strategic readers. While, Adebayo (2008) claims good method of teaching employed by teachers can enhance pupils reading ability.

Adebayo (2008), Aduwa-Ogiegbaen and lyamu (2006) explain that the teaching of reading competency is bedeviled with many problems such as inadequate period of teaching and lack of adequate and useful resources in schools. Lucas (2011) and Rany (2013) also note that pupils may have low reading ability due to school heads not availing the necessary course books for practice reading, lack of appropriate curriculum to help improve pupils reading abilities and classroom environments that are crowded and noisy for an appropriate teaching pedagogy to be fulfilled.

\section{Individual pupil factors contributing to low reading abilities}

The challenges teachers may face in teaching reading strategies to pupils may include pupils' lack of foundation in reading (Lucas, 2011; Rany, 2013). Pupils' inability to hear or produce a new sound in a second language has also been noted by Robertson (2009) as one of the challenges with which the teachers may face in teaching reading strategies in class. Sanford (2015) and Robertson (2009) highlight that one key factor that impedes pupils' reading ability is their inability to process 
the individual sounds of letters which is needed for word recognition; while Rany (2013) claims the limitations of pupils' vocabulary proficiency impedes their reading ability as well as a challenge to teachers when teaching reading strategies to pupils.

Sanford (2015) and Davenport (2002) point out that underdeveloped phonemic awareness and phonics skills do interfere with pupils' ability to read words fluently because reading is a technical process of reading letter by letter and word by word. This is why Swanson et al. (2009) assert that weak phonological retention processing results into poor reading abilities of pupils. Blending sounds within words (retaining phonological information) is essential for learning to read (Swanson, et al., 2009). Joseph (2018) also adds that pupils who become poor readers experience difficulties with accurately identifying and reading words at lower grades. The National Reading Panel (2000) concludes that the number one reason why pupils have low reading ability is their inability to master phonics (their inability to blend sounds together, to decode words and to break spoken words into their basic sounds).

Poor working memory is another factor that would contribute to pupils' low reading abilities. for instance, a larger number of scholars (Alloway et al., 2009; Swanson et al., 2009; Sanford, 2015) all claim that working memory allows a pupil to temporarily store information in short-term memory while being engaged in cognitive tasks. Thus, working memory helps pupils to activate prior knowledge about a topic while reading or using context clues to determine the meaning of a word (Alloway et al., 2009; Swanson et al., 2009). Alloway et al. (2009) and Swanson et al. (2009) assert that pupils with disabilities are known to have low working memory capacities.

Njie (2013) and Rany (2013) also assert that most pupils have low reading ability as a result of: lack of effective learning strategies, their unwillingness and lack of motivation to learn how to read. McRae and Guthrie (2009) propose that the best type of motivation to stimulate reading in pupil is the internal motivation (intrinsic motivation) where pupils' own interest in reading is what makes them to read. With intrinsic motivation, pupils become competent and highly achieving readers (McRae and Guthrie, 2009).

\section{METHODOLOGY}

A qualitative case study design was used in this study in order to identify participants' views and perceptions about the predominant factors contributing to the low reading abilities of pupils at Elsie Lund Basic School in the Tamale Metropolis. The time frame for the study was from August 2016 to March 2018. The case study design was chosen as it aided in the presentation and interpretation of detailed information concerning the predominant factors. The greatest advantage of case study is that it endeavours researchers to understand the problem under investigation (Mohammed and Molepo, 2017).

The researchers purposefully selected twelve teachers of the Elsie Lund Basic School with the belief that they are those who contain the most characteristics representation of the population. On the basis of the researchers' knowledge of the teachers' qualifications and experiences on teaching English as a second language in the basic schools, a Judgment was made about which classroom teacher was to be selected to provide the best information on the predominant factors contributing to the low reading abilities of pupils at the Elsie Lund Basic School in the Tamale Metropolis (McMillan and Schumacher, 2006). Furthermore, the reasons for the selection of the classroom teachers as participants of the study were that they are those actively involved in teaching the pupils for the past two years how to read and are also those tasked to ensure the implementation of effective reading strategies in class.

The limitation of the study was the use of only Elsie Lund Basic School in the Tamale Metropolis. There is the need for a large scale research which involves all Basic School Language teachers and their pupils in the Tamale Metropolis to help establish more predominant factors contributing to pupils' low reading abilities in schools.

Face-to-face in-depth individual interviews were used to collect data from the teachers through the use of field notes. Semi-structured interview schedule was designed for the twelfth face-to-face in-depth individual interviews session conducted. To validate the content and appropriateness of the interview questions, an English expert was acquired. Boyce and Neale (2006) explain that in-depth interviewing is a qualitative research technique that involves conducting intensive individual interviews with a small number of respondents to explore their perspectives on a particular idea or situation. In general, asking questions that were understandable to participants was an important part of the interviews session (White, 2005). Written consents were used to seek permission from the school proprietor and from the various classroom teachers to carry out the study. Participants were assured of confidentiality in the study's findings. They were also assured that their responses were only to be used for the purpose of the study and nothing else.

To ensure credibility and trustworthiness, the researchers considered the issue of bias when data was collected, sufficient time was given to the participants to answer the interview questions, and also, participants were used as member checks to corroborate the findings of the study before finalising (Mohammed and Molepo, 2017). Data was analysed thematically. This was where the researchers read and became familiar with the data and then identified the main themes from the data, they then examined the data and provided detailed descriptions of the participants' words and responses and finally categorised and coded the data and then grouped them into themes (Marie, 1997). 


\section{RESULTS}

The predominant factors found in the study which contribute to the low reading abilities of the pupils are: (i) inadequate confidence level of pupils, (ii) poor motivation given to pupils to stimulate their interest in reading, (iii) lack of pre-reader books in school and at home, (iv) low phonemic awareness skills of pupils and $(v)$ teacher inadequate knowledge on teaching phonemic awareness skills.

\section{DISCUSSION}

\section{Inadequate confidence level of pupils}

It was revealed in the study that low confidence level of pupils was a factor that contributes daily to pupils' low reading abilities in the school. The study found that the level of pupils' confidence in learning how to read in class was low and inadequate. Pupils are not in positions to try to practice reading and are also not prepared in class to try answering comprehension questions. The following voices came from two teachers: I can say their confidence level is low and inadequate, the self confidence is not there and also they lack "I can read spirit". Another teacher said: They lack confidence in trying to practice how to read. It is important to highlight here that the relationship between pupils' confidence and their academic performance has been elaborated by the National Academy of Sciences (2018) that pupils' perception of their ability or self-confidence is the central mediating construct of their achievement strivings in reading. Another teacher claimed: Pupil's confidence in reading lessons in class is not the best because most of them are still fresh readers (learning to read), in view of these, their confidence level is not adequate. To draw attention to why inadequacy of pupils' confidence in reading is a worrisome experience in teaching pupils how to read, the American Library Association (2018) highlights that confidence plays a huge role in a child's successes in reading and in other school subjects. To confirm this highlight made by the American Library Association (2018), the National Academy of Sciences (2018) concurs that the major influence in the acquisition of expert performance in reading by pupils is the confidence and motivation to persist.

\section{Poor motivation to stimulate pupils' interest in reading}

It was revealed that teachers and parents failed to stimulate pupils' interest in reading as such; the motivation level of the pupils to learn to read is inadequate. It was also found that both the school and the parents component are somehow reluctant to encourage pupils to develop positive attitude towards reading and there was inadequate parental involvement in assisting pupils learn how to read fluently at home. A teacher said the following: parents do not motivate their wards by helping them to read or learn to read at home. The importance of home influence on children reading abilities was highlighted by Lyon (2000) that children who have literacy experiences from birth have an edge in vocabulary development, reading and comprehension than those who lack literacy influence from home. Another teacher expressed the following sentiments: Some of the factors that impede reading skills are that parents sometimes do not buy pre-reader books for their wards on time and teachers too do not help pupils develop the passion to learn how to read in school. Lyon (2000) corroborated the finding by stating that children from homes where the parents' reading levels and practices are low are at increased risk of reading failure.

The study also found the school to have the tendency of not motivating pupils to read story books, word cards and to organise reading competitions among pupils. A teacher said the following: We have no reading competition among pupils in this school to motivate them read always. Another teacher commented that: The motivation level to encourage pupils to read story books in this school is low. It would have been better if the teachers could externally motivated the pupils to develop their interest in learning to reading as claimed by McRae and Guthrie (2009) that some of the external reasons why pupils read in school are: reading assignment been given to them by their teachers and the punishment teachers give to pupils when they fail to read in class.

The study established that language teachers themselves do not possess the requisite skills to motivate pupils to read and to become habitual readers. A teacher assertion was: Not enough motivation because teachers themselves do not possess the skills in teaching how to read. The finding is consistent with the findings of Rany (2013) who states that one of the reasons why pupils lack motivation to learn how to read is the fact that language teachers are not well-trained to teach reading in class as such, lack the teaching strategies to attract the interest of pupils in learning how to read.

\section{Lack of pre-reader books}

The study also found that the lack of pre-reader books and other reading materials in the school are some of the reasons why the pupils have low reading ability in the school. It was also found that the lack of pre-readers books such as: "I want to start reading vol. 1 and 2, my first picture reading book, my book of alphabets and letters" are some of the reasons why pupils have low reading ability in the school. A teacher made the following claim: The general factors that impede pupils reading skills in the pre-school are that pre-reader books are not used in the school. Another teacher claimed that our school lack reading books and materials such as I want 
to start reading vol. 1 and 2, my first picture reading book and my book of alphabets and letters. To concur with this finding, Lyon (2000) explains that pupils may have reading difficulties because of experience with limited reading books.

The study also revealed that word pronunciation and reading aloud have not been well taught in the school because of the lack of text books in the school. A teacher's views were: Lack of text books are the major barriers to teaching reading in this school this is because the books serve as guide to the pupils on how to learn to read. Another teacher expressed that: Pupils who do not have text books are not able to follow the whole class in a reading comprehension or read aloud lesson. This finding was confirmed by the findings of Aduwa-Ogiegbaen and lyamu (2006) and Adebayo (2008) in that the lack of text books and the lack of adequate and useful reader books are the reasons for pupils' low reading ability and performance in schools.

\section{Low phonemic awareness skills of pupils}

It was revealed in the study that pupils lack the knowledge in blending sounds within words and there are also signs of interferences in the ability of the pupils to fluently read out words. The following words came from a teacher: Reading ability of pupils in this school is low; this is due to the fact teachers do not teach them the knowledge on blending sounds with words. To confirm this finding, Joseph (2018) highlight that the most common cause of difficulties in acquiring early word reading skills is weakness in the ability to process the phonological features of language. Another teacher claims: I think the pupils in my class lack phonic skills in reading out letter by letter. To confirm this finding, Lyon (2000) states that deficits in the development of phoneme awareness skills by pupils goes a long way to affect their reading ability. Joseph (2018) concludes by stating that good word reading skills is one of the most critical skills required for effective comprehension of written material.

\section{Teachers' inadequate knowledge on phonemic awareness strategy}

The study found that language teachers in the school prepare inadequately when teaching reading lessons in class and also inadequate knowledge on how to teach phonemic awareness skills in class. Sentiment below came from a teacher. Lack of knowledge by us on teaching phonics is a factor which contributes to pupils' poor reading. Another teacher's opinion was that: The language teachers are sometimes not being able to pronounce letters and words adequately for pupils to hear and do the same. To concur with these findings, Lindner (2008) and Njie (2013) both believe the lack of exposure to reading strategies in class and the use of poor teaching methodologies by language teachers are some of the reasons why pupils have poor reading skills. To further corroborate with these findings, Botha et al. (2008) claim the problem of pupils' poor reading abilities is as the result of teachers not been trained to teach basic reading in class.

\section{CONCLUSION}

Despite the importance placed on early identification of reading difficulties in pupils and despite the call for language teachers to implement strategies meant to help pupils become fluent readers, at Elsie Lund Basic school in the Tamale Metropolis, there are pupils who struggle to read fluently as a result of being lazy, not being able to make reading a fun and pupils lack of interest in learning how to read. The additional factors that do contribute to the pupils' low reading ability in the school include: inadequate confidence level of pupils to read in class, inadequate motivation from teachers and parents to inspire pupils to read and the lack of pre-reader books and other reading materials in the school. Low phonemic awareness skills of the pupils and teachers' inadequate knowledge on how to teach pupils phonemic awareness skills in class also greatly contributed to the low reading ability of the pupils.

\section{RECOMMENDATIONS}

It is recommended that teachers instill in their pupils the academic significance of fluent reading. Teachers should build the confidence level of the pupils through implementing questioning techniques in reading discussion, that are age specific and where all answers to questions are accepted. Teachers should also build the confidence level of pupils in reading by making them read cooperatively, by encouraging each of them to read even if there are difficulties and by rewarding those pupils who have improved on their reading abilities.

The school authority must supply all pupils with adequate pre-reader books to facilitate the teaching and learning of reading in the school. It is also recommended that the supplied pre-reader books be age appropriate to facilitate the acquisition of reading skills by the pupils. Teachers should collaborate with the school head and parents of the wards in monitoring pupils' early developmental reading skills and in identifying and assisting those who require remedial instruction in reading.

At the home level, parents should help their wards develop interest in reading through assisting them to read fluently. Parents should have open-line of communication with their wards; they should ensure the supply of adequate pre-reader books and they should reward and complement their children for improved reading abilities and for upward educational achievements. The school 
should also motivate pupils to learn how to read fluently through organizing reading competitions among the pupils, giving pupils reading assignments and punishing those who fail to read fluently.

The Ghana Education Service should work with the school management team to highlight in their recruitment policy that only qualified English language teachers (Teachers with Bachelor of Education Qualification in English Language Teaching) are hired to teach English language in the basic school. The school management team should also partner with the Ghana Education Service to organize in-service training for the current language teachers were they are trained on phonemic awareness strategy in teaching reading skills.

\section{REFERENCES}

Adebayo, O. (2008). The impact of mother tongue on students' achievement in English language in Junior Secondary Certificate Examination in western Nigeria. Journal of Social Sciences, 17(1): 41-49.

Aduwa-Ogiegbaen, S. E., and lyamu, E. O. S. (2006). Factors affecting quality of English language teaching and learning in secondary schools in Nigeria. College Student Journal, 40(3): 495504.

Alloway, T. P., Gathercole, S. E, Kirkwood, H. J., and Elliott, J. E. (2009). The cognitive and behavioural characteristics of children with low working memory. Child Development, 80(2): 606-621.

American Library Association (2018). How Confidence Can Affect Children's Performances. [Online]. Available at http://mathandreadinghelp.org/articles/. Accessed: March 20th 2018.

Botha, D. Bizos, N., Gains, P., Moris, D., Place, J., and Puwani, H. (2008). National Reading Strategy. [Online] Available at http://www.gov.za/documents/. Accessed: May 24th 2017.

Boyce, C., and Neale, P. (2006). A Guide for Designing and Conducting In-Depth Interviews for Evaluation Input. [Online]. Available at http://www.cpc.unc.edu/. Accessed: May 16th 2017.

Caccamise, D., and Snyder, L. (2005). Theory and pedagogical practices of text comprehension. Topics in Language Disorders, 25(1): 5-20.

Cain, K., and Oakhill, J., (2011). Matthew effects in young readers: Reading comprehension and reading experience aid vocabulary development. Journal of Learning Disabilities, 44(5): 431-443.

Cekiso, M. (2012). Reading comprehension and strategy awareness of Grade 11 English secondary language learners. Journal of the Reading Association of South Africa, 3(1): 1-8

Darrel, M. (2005). The Howard Street Tutoring Manual: Teaching at-risk Readers in the Primary Grades. London: Guilford Press.

Davenport, T. (2002). South Africa: A Modern History, 2nd Edition, Johannesburg: Macmillan.

Grams, D. (2003). Motivating Students to Read Independently. (Online). Available at: http://goknow.com/GettingStarted/Documents/Grams_D_e-books.pdf. Accessed: 20th May 2018.

Harrington, P. E. (2001). Attracting New Teachers Requires Changing Old Rules. [Online]. Available at https://eric.ed.gov/?id=EJ625027. Accessed: August 17th 2017.

Jordaan, H. (2011). Language teaching is no panacea: A theoretical perspective and critical evaluation of language in education within the South African context. [Online]. Available at http://www.sajcd.org.za/. Accessed: April 20th 2017.

Joseph, K. T. (2018). Catch them before They Fall: Identification and Assessment to Prevent Reading Failure in Young Children. [Online]. Available at http://www.readingrockets.org/article/. Accessed: 20th June 2018.

Klapwijk, N., and Van de Walt, C. (2011). Measuring reading strategies knowledge for teachers to implement reading strategies instruction. Per Linguam: A Journal of Language Learning, 27(2): 2539.

Lindner, A. B. (2008). Informational Text Reading Strategy instruction and Relationship towards science. [Online]. Available at http://citeseerx.ist.psu.edu/viewdoc/download?. Accessed: January 25th 2018.

Lucas, M. (2011). Teacher Factors That Contribute To Poor Performance In English Language In Kenya. [Online] Available at http://ezinearticles.com/. Accessed June 14th 2017.

Lyon, G. R. (2000). Why Some Children Have Difficulties Learning to Read. [Online]. Available http://www.readingrockets.org/article/. Accessed 10th 2018.

Marie C. H. (1997). Choosing qualitative research: A primer for technology education researchers. Journal of Technology Education, 9(1): 47-63.

McMillan, J. H., and Schumacher S. (2006). Research in Education. 6th edition. America: Pearson Education, Inc.

McRae, A., and Guthrie, J. T., (2009). Promoting Reasons for Reading: Teacher Practices that Impact Motivation. New York: Guilford Press.

Moats, L. and Tolman, C. (2011.) Why Phonological Awareness is Important for Reading and Spelling. [Online] Available at http://www.readingrockets.org/. Accessed: March 20th 2017.

Mohammed, I., and Molepo, J. M. (2017). Barriers to the employment and promotion of teachers: The case of international teachers at secondary schools in the Mthatha Education District of South Africa. Ghana Journal of Development Studies, 14(2): 282-294.

National Academy of Sciences (2018). Self-Confidence and Performance. National Research Council. 1994. Learning, Remembering, Believing: Enhancing Human Performance. Washington, DC: The National Academies Press.

National Reading Panel (2000). Teaching Children to Read: An Evidence-Based Assessment of the Scientific Research Literature on Reading and its Implications for Reading Instruction [on-line]. Available at http://www.nichd.nih.gov/publications/nrp/report.cfm. Accessed June 11th 2017.

Njie, O. (2013). Gambia: Reasons why Students Fail English Language. [Online] Available at http://wwwallafrica.com/stories/201301110754. html. Accessed May 10th 2017.

Oberholzer, B. (2005). The relationship between reading difficulties and academic performance among a group of foundation phase learners. Journal of Higher Education, 16(3): 196-206.

Oyetunji, C. O. (2011). The Effect of Reading Strategy Instruction on L2 Teacher Trainees' Performance. University of South Africa, Pretoria. [Online]. Available at http://hdl.handle.net/10500/7760. Accessed February 4th 2017.

Rany, S. (2013). Factors Causing Students' Low in English Language in National University in Laos. International Journal of English Language Education, 1(1): 179-192.

Robertson, K. (2009). Reading 101 for English Language Learners. [Online] Available at http://www.colorincolorado.org/. Accessed: April 1 st 2017.

Sanford, K. L. (2015). Factors that Affect the Reading Comprehension of Secondary Students with Disabilities (2015). [Online]. Available at. http://repository.usfca.edu/diss/. Accessed April 10 2018.

Swanson, H. L., Kehler, P., and Jerman, O. (2009). Working memory, strategy knowledge, and strategy instruction in children with reading disabilities. Journal of Learning Disabilities, 43(1): 24-47.

Swanson, H. L., Zheng, X., and Jerman, O. (2009). Working memory, short-term memory, and reading disabilities: A selective metaanalysis of the literature. Journal of Learning Disabilities, 42(3): 260287.

White, C. J. (2005). Research: A practical guide. Pretoria: Ithutuko.

Citation: Mohammed, I., and Amponsah, 0. (2018). Predominant factors contributing to low reading abilities of pupils at Elsie Lund Basic School in the Tamale Metropolis, Ghana. African Educational Research Journal, 6(4): 273-278. 